\title{
The Analysis and Countermeasures of The Phenomenon of
}

\author{
NCEE Migrant
}

\author{
Liu Xuan \\ Mailbox420,No.2,Beinong Road,Huilongguan Town, ChangPing District,Beijing City \\ Email:472961992@qq.com
}

Keywords: NCEE migrant(National College Entrance Examination migrant) denifition causes proposals

\begin{abstract}
In China, the college entrance examination is a unified national entrance examination for common colleges recruiting students. The importance of the university entrance exam can be easily discovered, which plays a decisive role in a person's lifelong. With national citizens more and more concern for the college entrance examination ,some district governments have gradually introduced a series of policies to promote the reform and development of the college entrance examination system .But in recent years ,there are a number of reasons ,such as unreasonable dividing of admission line in different provinces ,the huge distance of education resources between diverse regions ,no coordination between the college entrance examination and its relevant mechanism and so on, lead to the emergence of the phenomenon of the college entrance examination immigration and have intensified trend .This article will offer proposals for the reform and development of the college entrance examination system and the promotion of the educational equality ,through analyzing the causes of NCEE migrant.
\end{abstract}

\section{The Definition of NCEE Migrant}

NCEE Migrant (National College Entrance Examination migrants) refers to some examinees ,in order to be admitted to an university or even better ,immigratt to some regions that have lower admission line and higher admission rate through transferring household registry or school roll ,etc. At home, the candidates who emigrate for exam mainly come from the areas, which have more examinees, higher entry score line and lower enrollment rate ,such as Shandong ,Anhui ,Hubei and so on .In contrast, there are various types of inflow areas because of multitudinous demands of examinees .It is mainly divided into the following kinds :First, the districts with better educational foundation but lower admitted fractional line ,such as Beijing ,Shanghai and other first-tier cities .Second, the areas that have worse educational foundation, lower admission line and higher admission rate ,such as Hainan ,Shanxi and other western backward areas or remote areas.Third ,the regions ,like Xinjiang and Inner Mongolian ,which enjoy the preferential policy of our countries .It was a particular type that had to mention .Several examinees’ parents spend heavily in purchasing passport of such Philippines, Vietnam, Laos and other southeast Asian developing countries ,so that their children can get admissions of domestic key university as 
students abroad. It is known as the international college entrance examination immigration by this way. ${ }^{[1]} \square \square$

\section{The Causes of NCEE Migrant}

Unreasonable Dividing of Admission Line in Different Provinces.

(refer with: Table 1 admission line of college entrance examination scores of the part of the provinces or municipalities of 2015 of China)

\begin{tabular}{|c|c|c|c|c|c|c|c|c|c|c|}
\hline $\begin{array}{l}\text { Pronvince/Munici } \\
\text { palty }\end{array}$ & \multicolumn{2}{|c|}{ Beijing } & \multicolumn{2}{|c|}{ Shanxi } & \multicolumn{2}{|c|}{$\begin{array}{l}\text { Inner } \\
\text { Mongolia }\end{array}$} & \multicolumn{2}{|c|}{ Shandong } & \multicolumn{2}{|c|}{ Anhui } \\
\hline $\begin{array}{l}\text { admission line of } \\
\text { college entrance }\end{array}$ & $\begin{array}{l}\text { art } \\
s\end{array}$ & $\begin{array}{l}\text { scien } \\
\text { ce }\end{array}$ & $\begin{array}{l}\text { art } \\
\mathrm{s}\end{array}$ & $\begin{array}{l}\text { scien } \\
\text { ce }\end{array}$ & $\begin{array}{l}\text { art } \\
\mathrm{s}\end{array}$ & $\begin{array}{l}\text { scien } \\
\text { ce }\end{array}$ & $\begin{array}{l}\text { art } \\
\mathrm{s}\end{array}$ & $\begin{array}{l}\text { scien } \\
\text { ce }\end{array}$ & $\begin{array}{l}\text { art } \\
\mathrm{s}\end{array}$ & $\begin{array}{l}\text { scien } \\
\text { ce }\end{array}$ \\
\hline $\begin{array}{l}\text { examination } \\
\text { scores(points) }\end{array}$ & $\begin{array}{l}47 \\
7\end{array}$ & 452 & $\begin{array}{l}38 \\
2\end{array}$ & 350 & $\begin{array}{l}38 \\
5\end{array}$ & 336 & $\begin{array}{l}51 \\
0\end{array}$ & 490 & $\begin{array}{l}52 \\
2\end{array}$ & 483 \\
\hline
\end{tabular}

From table 1 ,it can be seen clearly that between the inflow areas ,which are represented by Beijing, Shanxi and Inner Mongolia ,and the outflow areas, which are represented by Shandong ,Anhui ,whether liberal arts or science ,exiting huge distance in admitted fractional line .Opening our eyes to the whole nation , the biggest distance of arts' admission line is above 200 points , meanwhile , the biggest gap of science's admission line is nearly 180 points.

Through these datas, we can realize there are giant distance of admitted fraction line of the college entrance examination between different provinces or municipalities .

The Huge disparity of Education Resources between Different Regions.As is well-known , on account of a vast territory in our countries ,there is an tremendous gap of social economic development in different provinces or regions . Objectively , it also gives rise to basic conditions of the development of education in disparate starting line between different regions .First of all ,in terms of senior high school, compared to backward areas, developed areas have more excellent teachers' faculty and more advanced teaching equipment .Therefore ,an enormous disparity exit in all aspect of senior high school students who they have cultivated .In the next place , as far as the distribution of college to be concerned ,according to the top one hundred college in 2015 ,both Beijing and Jiangsu are far ahead,which possess 15 listed universities .However, Inner Mongolia , Xinjiang and some other provinces have no colleges on the list. ${ }^{[2]}$

Owing to the great gap of educational resources in different districts ,the examinees and their parents make the choice to emigrate for the college entrance examination, which is based on the game of interests .

No Coordination between the College Entrance Examination and its Relevant Mechanism .In the last few years in our countries , governments, in succession ,have formulate policies for the sake of promoting educational equity .For instance, the policy of extra marks for the ethnic minority groups and of migrant students sitting for the National College Entrance Exam .Nevertheless ,in the process of a series of reforms, the mechanisms that associated with these policies haven't be perfected at the same time .Besides, there have no matching problems on the household 
registration system and student status system , which are both related to the National College Entrance Exam .

Due to the National College Entrance Exam and its correlated mechanism are in different steeps ,There are excellent chance to pick up the leak of the institution for the immigrant examinees .Even worse, this phenomenon is overflowing .

\section{The Proposals of the NCEE Immigrant}

The phenomenon of the NCEE migrant robs the higher educational resources by using improper means, which is a kind of destruction of social justice undoubtedly . News reports from all over the country, it can make out that several local governments have the determination of striking the NCEE immigrant . Whereas there are still a few of people hold fluky psychology to confront with the government through more and more sophisticated methods .Hence, only the authorities intensify to attack the migrants of NCEE,can not leave them the slightest space to taking advantage of a weak point .

Improve the Existing Supporting Policies and Fill the Hole.When people mentioning the mobile population for college entrance examination, it is always said that those people who take advantages of the loopholes in the system .In the other words, the saying indicates that there are vulnerability of present college entrance examination system in a certain extent .In the first place, we must start from the source and make up the loophole if wanting to put an end to this phenomenon .

Perfect the college matriculation policy for migrant children and increase the number of year of student status. With the development of urbanization and industrialization ,a part of rural migrant workers move to the cities with their families.$^{[3]}$ Then, the policy has came forth, which allows children of migrant workers to enter senior high schools and sit college entrance exams locally for purpose of acquiring fair educational rights for those children. Following the implementation and gradual relaxation of the policy, the problem about the NCEE immigrant has came into being .On one hand, we shouldn't abandon the college matriculation policy for migrant children for the sake of striking the NCEE immigrant .On the other hand, we can't permit the examinees and parents, who devote themselves to emigrate for the college entrance exam ,to fish in troubled waters by confusing the two policies. In the face of such a institutional dilemma ,no matter the authorities or the public ,should reinforce cognition and clearly distinguish from these two policies .Furthermore ,make a certain fixed number of the year of the student school roll as an essential condition of sitting college entrance exam locally . In the mean time ,the high school should provide necessary proofs, which affirm those children of migrant workers having been in here .Only in this way ,can we rule out immigrant examines who airborne for the college entrance examination or who only hand their status in one school but not studying in here .

Improve the household registration system and boost the number of year of paying tax of their parents .In China today ,exiting urban and rural household registration system has divided people to citizen or village residents .Actually, this way is a hierarchical order in another measure, which directly reflected in unfair education. 
Rural children cannot enjoy the advanced education resources in the city because of the nearby principle in the period of compulsory education. As a consequence ,those student who squeeze in a key senior high school in the town can be counted on fingers .We can easily understand country side people move to the city for better education .But those who emigrate from developed areas to somewhere else are for the sake of what .

Many Chinese provinces and municipalities have announced a number of policies to drive local economy . For example ,Hainan province used to introduce policy that explicitly stipulates someone can obtain a household by buying every 25 square meters and then can acquire college entrance exam opportunity the same with the indigene $\cdot{ }^{[4]} \mathrm{At}$ this point , former question is solved .

The behavior ,which loots higher educational resources by short-term purchase or investment, is so unfair to the local who have lived in here in a long time .Under this premise , increase the number of year of rate payment of immigrant examinees' parents and of social security contribution. Whether living in the place of sitting college entrance examination or not ,must be indispensable element .So that ,we can exclude those who only purchase apartments in here .

Push the Process Of education .Narrow the regional gap of educational level and balance the educational resources .This unfair immigrated examinees for NCEE phenomenon roots from the inequality of Chinese education itself .It is well known that there are significant differences of educational resources in disparate regions in our country .Just think about it .If the level of education between different areas were in the same pace ,the NCEE immigrant will lose motivation or not?

Education fair is an important measure of realizing the social fairness .In the last few years, sit-in ,boycotting classes and demonstrations happened to protest to the NCEE immigrant in Hainan, Gansu and other provinces .Such things seriously affect the whole social harmony and stability .Compared to the advance educational sources of developed areas and the lean college entrance examination admission line ,it was far from enough that these remedy measures for the examinees of undeveloped areas by governments ${ }^{[5]}$ So as to make up this disparity , most of all things, government need to enlarge educational input of backward areas instead of covering up the unfair of education by means of slant enrollment mark .

Innovate the exam and matriculate of NCEE system .Nowadays, our country has carried out the compounded regime of the regional exam and the national exam with the principle of distributing quotas and implementing province-based enrollment scores .However, equitable as these policies are looked like, the examinees who are come from such as Hebei, Shandong, Hubei and other mass students provinces ,emigrate to less developed areas for NCEE at all costs .Those students receive advanced teaching in their own provinces and then take a simpler test paper and compete with the lower level in less developed regions .This way ,the students who may not get into higher vocational college originally ,admitted to undergraduate course .What's more, those students whose grades are so-so get admission of a key university . For example, the student with the top National College Entrance 
Examination score at arts was confirmed as a NCEE migrant in Yulin City in Shaanxi Province in 2015 .

The author of in this essay is not to blindly deny the current college entrance examination system in our country, but merely deem that is far from perfection .As far as the examination system is concerned ,the college should possess a certain authority of test on the basic of national exam .Under the uniformly prescribed of college admission scores line, candidates can declare ideal college in their own minds .And then participate in the admitted text, which is organized by the college itself .By this conjunct form ,on one side ,it adds threshold to the immigrant examinees who hold fluky mind and checkout their true skill and genuine knowledge .On the other side ,it contributes the college to select students, which are really suitable for their own in a batch of similar level .In terms of college admission institution ,"No matter where you choose to take test ,it has always been your former provincial quota ". ${ }^{[6]}$ In this article, I define the former province as the place where student status have registered in the longest time during student career. In brief ,candidates no matter where they move latterly and where they intend to take college entrance exam ,the admission quota belongs to the place where their school rolls register the longest time .That is to say ,how many the number of admission quota this region increase based on the number of external admitted test- takers. Simultaneously ,decrease enrolment quantities of these examinees former provinces .

Perfect the Corresponding Laws and Strengthen Social Supervision .Amplify legal responsibility .In the last decade , many Chinese provinces and municipalities have taken measures to crack down the phenomenon of mobile population for College Entrance Examination . For example ,Xinjiang province stipulates ,every middle school can't accept the sign up of the students whose student roll is not registered in this school .Moreover ,according to Inner Mongolia ,a person who emigrate from another province and their families but not studying in this autonomous region, can't register for ordinary universities ${ }^{[7]}$ The news about depriving the test and admission qualifications from immigrants for NCEE are reported occasionally .Even now ,the phenomenon of NCEE immigrant failed to eliminate thoroughly. There are still a part of parents carry minds ,if not be found ,by luck. What they think are that take a moment of adventure to exchange with happy lifelong .

Such fluke mentality has existing on account of the voice of the system higher than the voice of the law in the measures of attacking the NCEE immigrant . At present, relying on the government to block and punishing emigrant candidates merely can only increase the cost of the NCEE immigrant and augment the burden of education department .Worse still, it will obstruct impartial and lawful job of administrative organ of government ${ }^{[8]}$ The immigrant candidates do not need to bear the statutory responsibility .Meanwhile, local examinees not have proper legal weapon to vindicate violable rights. As the result of these two status, the phenomenon of migration for college entrance examination is becoming even more fierce .Therefore, the authority should perfect relevant laws and regulation and make the NCEE immigrant become illegal by expressly stipulation. What the most important is that aggravate the legal liability of immigrant examinees ,their families 
and interrelated intermediary or deputy organization .Only by above way ,can we eliminate the NCEE immigrant fundamentally .

Strengthen verification of identity and open information channel .Under various of striking policies of government, several people can still make waves.The reasons of that is a strong background supporting for them if not the fake identity is hard to discover .It was indispensable to enhance identity review . "It is necessary to set up a specialized website to share resources," ${ }^{[9]}$ which records fundamental messages and student status information from primary school to senior high school of the all candidates. Such a nation-examinee information exchange system is convenient to examine their identity .

Besides ,the government should set up convenience trenches for whistle-blowing ,so that can intensify social surveillance of the NCEE immigrant .On one hand ,use the acute eyes of the public to find delitescent immigrant students ,which can improve administrative efficiency of government .On the other hand ,it is also supervision to government's work .The public have chance to disclose the malfeasance of government or civil servants .Besides, lay the better social environment for striking the National College Entrance Exam migrant .

To sum up ,in the face of inundant phenomenon of migration for national college entrance examination all the time, our government should not use the method on "one size fits all" ,and shut off all special policies about the college entrance examination.Without no doubt, it was far from enough to depend on unarmed combat of the authorities barely .Facing this dilemma ,the government should undertake the uppermost responsibility actively to solve problems and then pick up the weapons of laws and the people to fight against difficulties .Only by above way ,can we make the phenomenon of national college entrance examination immigrant less and less .

\section{References}

[1] Xia Quan, YU Baoshan, The Perspective of The International College Entrance Examination Immigration, Journal of National Academy of Education Administration,1672-4038 (2011) 10-0067-05

[2] The Chinese University Evaluation in 2015 ,Chinese administration Science Study Academy

[3] Liu Hui ,the Distinction of Concept between College Matriculation Policy for Migrant Children and the Policy Proposal ,Educational Science Rearch ,2013(6)

[4] the Notice about the Circulation Problem of the Dacklog of Commercial Housing by General Office of Hainan Province ,NO.119 Document of General Office of Hainan Province

[5] Wei Guodong , On the Reform of China’s NCEE since 1997 ,A Dissertation for the Degree of D.Education, 10075 
[6] Zhai Yueling , On the Root of "The Immigration Policy of Entrance Exam in the University” , Beijing Normal University, Beijing 100875; Law School, Liaocheng University, Liaocheng 252000

[7] DAI Yun ,The Legal Analysis on the Phenomenon of Blocking the Emigrants of National Examination ,Fudan Education Forum 2005. Vol.3,No.5

[8] Miu Susheng ,The Legal of Migration for College Entrance Examination ,Administrative Forum ,2004.10

[9] Xia Quan, YU Baoshan, The Perspective of The International College Entrance Examination Immigration, Journal of National Academy of Education Administration,1672-4038 (2011) 10-0067-05 